\title{
INFLUENCE OF DIETARY CARROT AND PAPRIKA ON EGG PHYSICAL CHARACTERISTICS AND YOLK COLOR
}

\author{
Nedeljka J. Spasevski, Danka M. Dragojlović, Dušica S. Čolović, Strahinja Ž. Vidosavljević, Tatjana \\ A. Peulić, Slađana M. Rakita, Bojana M. Kokić
}

University of Novi Sad, Institute of Food Technology, 21000 Novi Sad, Bulevar cara Lazara 1, Serbia

\author{
*Corresponding author: \\ Phone: +381214853807 \\ Fax: +38121450725 \\ E-mail address: nedeljka.spasevski@fins.uns.ac.rs
}

\begin{abstract}
For many consumers egg yolk color is a very important characteristic of egg quality. Since hens are not able to synthesize coloring pigments, the intensity of the yolk color depends directly on the content and profile of pigmenting carotenoids present in their feed. The aim of this study was to assess the combined pigmenting effect of paprika and carrot and their ability to achieve egg yolks in the desired color range. Biological tests lasted for 30 days and were conducted on 180 Lohmann Brown layers. The laying hens were divided in six groups. Every group was assigned to one of six possible treatments, control 1 (C1) treatment without any pigments added, control 2 (C2) treatment with synthetic pigments added and four experimental diets (D1, D2, D3, D4) with the addition of natural color sources (paprika and carrot). After experimental period collected eggs were analyzed regarding physical characteristics of eggs, content of $\beta$-carotene and yolk color of eggs. Obtained results has shown that dried carrot and milled paprika can successfully replace synthetic pigments, with no negative effects on physical characteristics of produced eggs, egg yolk color, acceptability or $\beta$-carotene content.
\end{abstract}

Key words: natural pigments, yolk color, CIE $L^{*} a^{*} b^{*}$, sensory analysis, $\beta$-carotene

\section{INTRODUCTION}

According to the conducted surveys, most of the consumers highly value a number of different characteristics of the egg, but especially the shell strength, albumen consistency, and the yolk color (Hernandez et al., 2005). The most preferred yolk color is ranging from golden yellow to orange (Chowdhury et al., 2008), depending on the world region.

Since hens are not able to synthesize coloring pigments, the intensity of the yolk color depends directly on the content and profile of pigmenting carotenoids present in their feed (Hernandez et al., 2005). Natural sources of carotenoids can be used in laying hen's diet, such as yellow maize, marigold, alfalfa, carrot, pumpkin, paprika, etc. The combination of natural sources also has influence on yolk color. For achieving a golden yellow yolk color diets have to be supplemented with both yellow and red pigments (Grashorn and Steinberg, 2002). Yellow xanthophylls are needed to achieve a correct yellow base 
coloration but are not allowed to reach RYCF (Roche Yolk Colour Fan) values higher than 13 at commercial inclusion levels, because they are not economical (Galobart et al., 2004).

For example, marigold alone cannot give the color of the yolk which consumers demand and must be combined with paprika. The addition of paprika alone, or in combination with marigold, increases the content of $\beta$-carotene, redness value and RYCF (Spasevski et al., 2017).

The scavenging hens always produce acceptable yolk color due to their free access to green plant that contain abundant xanthophyll pigments (Chowdhury et al., 2008). However, most of the farm hens use high energy concentrated feed, which is low in natural pigments, especially in diets that contain inadequate amounts of yellow corn.

The most commonly used ingredient for yolk pigmentation is yellow corn, which contains $20-25 \mathrm{mg} / \mathrm{kg}$ of xanthophylls (Chowdhury et al., 2008). Since in some countries corn cultivation is very limited, producers are dependent on other grains such as wheat, barley, oat etc. in diet formulation.

These grains are deficient in desirable pigments; therefore the use of natural or synthetic pigments is an alternative measure for egg yolk coloration (Chowdhury et al., 2008).

Synthetic pigments are two or three times more efficient as a yolk colorant than carotenoids of vegetable origin.

Furthermore, they have high stability due to encapsulation against oxidation and degradation (Deepa et al., 2007). Most commonly used synthetic pigments, which are chosen because of their coloring effecttiveness, are cantaxanthin and citranaxathin.

Use of synthetic pigments increases feed costs, and in some countries its inclusion is often prohibited by government regulations.

There is assumption that canthaxanthin causes deposition of color crystals in the retina (EFSA, 2014). The crystals may damage the retina and may impair visual acuity (Grashorn and Steinberg, 2002). Therefore, the Scientific Committee on Food (SCF) in 1997 assumed that the reliable residue level of canthaxanthin in eggs was $0.2 \mathrm{mg}$ per egg (SCF, 1997).

Furthermore, in 2002 the European Union Scientific Committee for Animal Nutrition suggested a maximum supplementation level to animal diets of $8 \mathrm{mg} / \mathrm{kg}$ canthixanthin in diet for laying hens and 25 $\mathrm{mg} / \mathrm{kg}$ in diet for broiler.

Nowadays, there is high tendency for replacing the synthetic pigments with natural sources, since these products have some potential negative health effects and their use in organic production is forbidden.

Over recent years, there has been a market trend toward the use of natural supplements in animal nutrition. During the history pepper has been used to enhance the red color and pungency of foodstuffs.

More than 50 identified structures of carotenoids are responsible for red color of red pepper Capsicum annum (Cervantes-Paz et al. 2014).

Also, it contains from 0.3 to $3.2 \mathrm{~g} / 100 \mathrm{~g}$ dry weight of carotenoids (Arimboor et al., 2014). Capsanthin, capsorubin and cryptocapsin impart red color to paprika, while the yellow orange color is from $\beta$-carotene, zeaxanthin, violaxanthin and $\beta$-cryptoxanthin.

Red paprika is a good egg colorant, and it does not have any negative effects on hens' productivity parameters (Gurbuz et al., 2003; Rowghani et al., 2006). Carrot contains higher amount of carotenes and minor amount of xanthophylls.

Due to its low economic value, low quality carrot and its discarded parts can be used as carotenoid source in animal feed. Furthermore, they have high potential to become a forage material in organic egg production (Hammershøj et al., 2010).

The aim of this study was to assess the combined pigmenting effect of paprika $C$. annuum and carrot and to see if the combined pigment sources could achieve egg yolks in the desired color range. 
Table 1.

Formulation of the experimental compound feeds

\begin{tabular}{lcccccc}
\hline Ingredients (\%) & C1 & C2 $^{*}$ & D1 & D2 & D3 & D4 \\
\hline Maize & 58.7 & 58.7 & 57.8 & 57.7 & 57.7 & 57.7 \\
Soybean cake & 21.1 & 21.1 & 20.6 & 20.7 & 20.7 & 20.8 \\
Sunflower meal (33\% protein) & 9.8 & 9.8 & 9.8 & 9.8 & 9.8 & 9.8 \\
Limestone & 6.28 & 6.28 & 6.28 & 6.28 & 6.28 & 6.28 \\
Premix & 4 & 4 & 4 & 4 & 4 & 4 \\
Methionine-DL (99\%) & 0.018 & 0.018 & 0.018 & 0.018 & 0.018 & 0.018 \\
Dried carrot & - & - & 1.5 & 1.0 & 0.5 & - \\
Milled paprika & - & - & - & 0.5 & 1 & 1.5 \\
\hline${ }^{*}$ with added synthetic pigments (arophyll red
\end{tabular}

*with added synthetic pigments (carophyll red $0.05 \mathrm{~g} / \mathrm{kg}$ and carophyll yellow $0.01 \mathrm{~g} / \mathrm{kg}$ )

Table 2.

Chemical composition of control and experimental diets

\begin{tabular}{lcccccc}
\hline Chemical composition (\%) & C1 & C2 & D1 & D2 & D3 & D4 \\
\hline Dry matter & 89.64 & 89.82 & 89.69 & 89.67 & 89.75 & 89.79 \\
Moisture & 10.36 & 10.18 & 10.31 & 10.33 & 10.25 & 10.21 \\
Crude protein & 16.29 & 16.73 & 16.70 & 16.70 & 16.30 & 16.41 \\
Crude fat & 3.92 & 3.95 & 3.86 & 4.02 & 4.30 & 4.24 \\
Crude ash & 11.10 & 11.46 & 11.17 & 11.49 & 10.97 & 11.64 \\
Crude fibre & 3.63 & 3.70 & 3.77 & 3.86 & 3.68 & 4.06 \\
Calcium & 3.26 & 3.29 & 2.82 & 3.24 & 2.86 & 0.47 \\
Available phosphorus & 0.41 & 0.36 & 0.60 & 0.57 & 0.47 & 0.55 \\
\hline
\end{tabular}

\section{MATERIAL AND METHODS}

\section{Feed treatment}

Biological tests were carried out at a poultry farm located in Vilovo, Serbia. The corresponding research lasted 30 days and was conducted on 180 Lohmann Brown layers, which were randomly placed in individual wire cages with free access to the feed and water and identical care provided for each of the birds. The laying hens were divided in six groups, with six replicates of five birds each. Every group was assigned to one of six possible treatments, control 1 (C1) treatment without any pigments added, control 2 (C2) treatment with synthetic pigments added and four experimental diets (D1, D2, D3, D4) with the addition of natural color sources.

Basal diet, which represented the C1 treatment, was consisted of conventional raw materials and was used as a base for formulating $\mathrm{C} 2$ and the other four treatments (D1-4), by supplementing the basal diet with synthetic pigments, or ad- ding red milled paprika or dried carrot (or combination of thereof) in different concentration ratios according to Table 1 . The nutritive information of control and experimental diets were analyzed and presented in Table 2.

\section{Sample collection and analyses}

At the end of the planned experimental period, ten representative eggs from each of six treatments were randomly collected. Collected eggs were analyzed regarding physical characteristics of eggs, content of $\beta$-carotene and yolk color of eggs. Weight of whole egg, egg shell, yolk and albumen were monitored throughout the study. Egg shell and yolk were weighted separately.

Albumen weight was calculated as difference between whole egg weight and total weight of egg shell and yolk. Results for yolk color of eggs were obtained by comparing with the RYC fan (Hoffmann-La Roche Ltd, Basel, Switzerland), within the range of yolk colors from 1 (very light yellow) to 15 (dark orange). Yolk color was also determined by using Minolta Chroma 
Meter (Model CR-400, Minolta Co., Osaka, Japan), and all measurements were conducted on whole egg at three places on the sample (one at the centre and two on the side).

The instrument was calibrated against a standard light white reference tile and the measurements conducted under standard illuminant D65, a $2^{\circ}$ standard observer angle. The color parameters $L^{*}$ - lightness (- black, + white), a*- red/greenness (green, + red), $b^{*}$ - blue/yellowness (- blue, + yellow) were determined and results were expressed in accordance to the CIELab color system. For the purpose of the $\beta$-carotene quantification, the method described by Islam and Schweigert (2015) was used in this study. Results obtained by analyzing the $\beta$-carotene content were expressed as $\mu \mathrm{g} \beta C / \mathrm{g}$ sample.

\section{Sensory analysis}

Seven trained panelists aged between 31 and 59 years participated in the sensory evaluation recruited from the staff of the Institute of Food Technology (Novi Sad, Serbia), according to SRPS EN ISO 8586 (2015).

Panelists visually evaluated acceptability of fresh egg yolk color under laboratory condition. This parameter was judged using a five-point category scale: 5 , acceptable; 4, almost acceptable; 3, nor acceptable nor unacceptable; 2, almost unacceptable and 1, unacceptable. Eggs were marked with a special code among assessors and presented on plastic plates.

\section{Statistical analyses}

One way analysis of variance (ANOVA) was used to test the influence of different source of pigments and pigment combinations on egg production and yolk color. The differences between treatment means were assessed with a Tukey's HSD test at $p<0.05$. The data were statistically analyzed using the Statistica software version 13 (Statsoft Inc. 2013, USA).

\section{RESULTS AND DISCUSSION}

Physical characteristics of produced eggs were measured in order to ensure that there is no negative effect of natural pigment sources in hens feed on eggs production. The results are shown in Table 3. No significant differences in any of measured parameter were observed, as it can be noticed.

Table 3.

Physical characteristics of produced eggs

\begin{tabular}{lcccc}
\hline & Egg weight $(\mathbf{g})$ & Yolk weight $\mathbf{( g )}$ & $\begin{array}{c}\text { Albumen weight } \\
\mathbf{( g )}\end{array}$ & $\begin{array}{c}\text { Egg shell weight } \\
\mathbf{( g )}\end{array}$ \\
\hline Control 1 & $68.39 \pm 6.74^{\mathrm{a}}$ & $17.60 \pm 2.18^{\mathrm{a}}$ & $43.99 \pm 4.18^{\mathrm{a}}$ & $6.80 \pm 1.17^{\mathrm{a}}$ \\
Control 2 & $68.42 \pm 3.14^{\mathrm{a}}$ & $17.51 \pm 1.63^{\mathrm{a}}$ & $43.49 \pm 1.66^{\mathrm{a}}$ & $7.42 \pm 0.33^{\mathrm{a}}$ \\
Diet 1 & $66.29 \pm 5.02^{\mathrm{a}}$ & $17.19 \pm 2.12^{\mathrm{a}}$ & $42.08 \pm 3.80^{\mathrm{a}}$ & $7.02 \pm 0.74^{\mathrm{a}}$ \\
Diet 2 & $68.11 \pm 1.39^{\mathrm{a}}$ & $17.09 \pm 0.68^{\mathrm{a}}$ & $43.90 \pm 1.28^{\mathrm{a}}$ & $7.13 \pm 1.12^{\mathrm{a}}$ \\
Diet 3 & $64.73 \pm 2.37^{\mathrm{a}}$ & $15.91 \pm 1.49^{\mathrm{a}}$ & $41.54 \pm 3.53^{\mathrm{a}}$ & $7.29 \pm 0.35^{\mathrm{a}}$ \\
Diet 4 & $68.98 \pm 7.44^{\mathrm{a}}$ & $16.06 \pm 1.27^{\mathrm{a}}$ & $48.92 \pm 2.90^{\mathrm{a}}$ & $7.34 \pm 0.25^{\mathrm{a}}$ \\
\hline
\end{tabular}

Results are expressed as mean \pm standard deviation (SD) for ten replicates

Table 4.

Color of egg yolk determined with Minolta Chroma Meter and with RYCF

\begin{tabular}{lcccc}
\hline & \multicolumn{3}{c}{ CIE Lab } & RYCF \\
\cline { 2 - 4 } & $\boldsymbol{L}^{*}$ & $\mathbf{a}^{*}$ & $\boldsymbol{b}^{*}$ & \\
\hline Control 1 & $51.68 \pm 1.7^{\mathrm{b}}$ & $-0.79 \pm 0.7^{\mathrm{a}}$ & $36.19 \pm 3.2^{\mathrm{b}}$ & $7.67 \pm 0.5^{\mathrm{a}}$ \\
Control 2 & $46.57 \pm 1.3^{\mathrm{a}}$ & $12.52 \pm 1.4^{\mathrm{c}}$ & $29.09 \pm 3.5^{\mathrm{a}}$ & $14.63 \pm 0.5^{\mathrm{c}}$ \\
Diet 1 & $51.91 \pm 1.3^{\mathrm{b}}$ & $0.13 \pm 0.2^{\mathrm{a}}$ & $34.99 \pm 3.2^{\mathrm{abc}}$ & $8.67 \pm 0.8^{\mathrm{a}}$ \\
Diet 2 & $49.00 \pm 2.0^{\mathrm{ab}}$ & $8.71 \pm 1.0^{\mathrm{b}}$ & $35.00 \pm 3.9^{\mathrm{bc}}$ & $12.57 \pm 0.5^{\mathrm{b}}$ \\
Diet 3 & $45.69 \pm 2.7^{\mathrm{a}}$ & $12.82 \pm 2.7^{\mathrm{c}}$ & $30.22 \pm 3.2^{\mathrm{ac}}$ & $14.33 \pm 0.5^{\mathrm{c}}$ \\
Diet 4 & $45.55 \pm 2.1^{\mathrm{a}}$ & $17.66 \pm 1.0^{\mathrm{d}}$ & $32.01 \pm 4.2^{\mathrm{abc}}$ & $14.71 \pm 0.5^{\mathrm{c}}$ \\
\hline
\end{tabular}

Results are expressed as mean \pm standard deviation (SD) for ten replicates 




Figure 1. Beta-carotene content in produced eggs
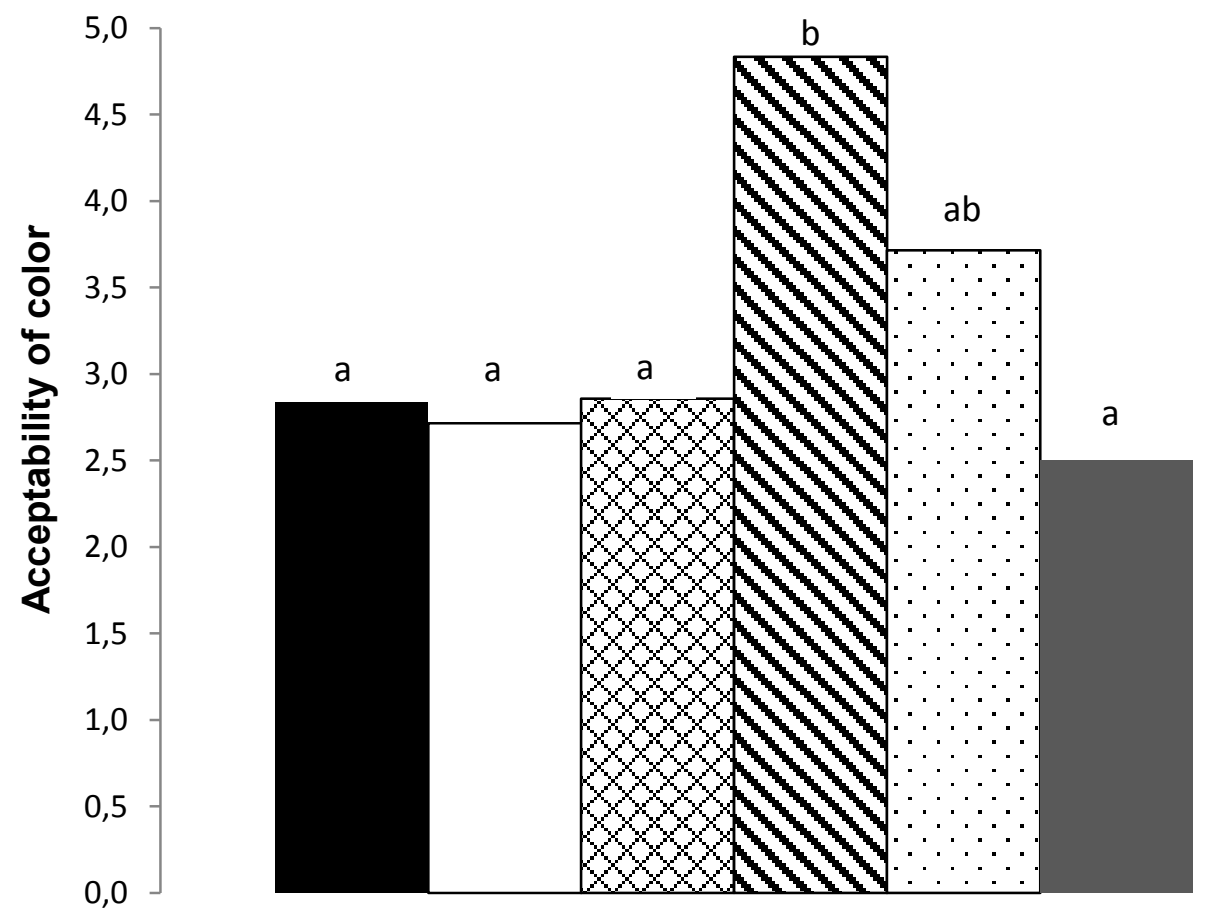

- Control 1

$\square$ Control 2

口Diet 1

Diet 2

ㅁiet 3

Diet 4

Figure 2. Acceptability of color of produced experimental eggs

These results are in consistence with similar experiments conducted in order to replace synthetic colorants by natural pig- ments. As shown by Lokaewmanee et al. (2011), addition of marigold and paprika in laying hens diet did not affected physical 
properties of eggs. The same conclusions were presented by Rowghani et al. (2006) and Chowdhury et al. (2008). Fig. 1 shows changes in $\beta$-carotene content in eggs' yolk with changes of paprika and carrot ratio in hens' diet. Beta-carotene content was the highest in eggs of hens fed with Diet $4(1.5 \%$ of milled paprika and $0 \%$ of dried carrot) and accounted $47.97 \mu \mathrm{g} / \mathrm{g}$.

This level of $\beta$-carotene was higher even than $\beta$-carotene content in eggs of hens fed with diet Control 2, which contained synthetic pigments in amount recommended by the manufacturer. Natural $\beta$ carotene consists of two isomers: all-trans and 9 -cis and is present only in natural environments, whereas synthetic $\beta$-carotene contains only the all-trans isomer, which has lower liposolubility and lower antioxidant property than 9-cis isomer (Spasevski et al, 2016).

It is obvious from Fig. 1 that with increase in paprika ratio in the diet, content of $\beta$ carotene also increased. Similar conclusions were presented in paper of Spasevski et al. (2017) when compared paprika and marigold as a natural sources of pigments in laying hens diets.

Results of $L^{*}$ and $a^{*}$ presented in Table 4 has shown that Diet 3 and Diet 4 were very similar to Control 2 diet, with higher redness in Diet 4 comparing to Diet 3 and Control 2 diet, which indicates that by addition of milled paprika the same color as by the addition of synthetic pigments, even redder, can be achieved.

Also, according to the mentioned parameters Diet 1 was similar to Control 1 diet where no pigments were added, which means that by addition of dried carrot alone favorable egg yolk color cannot be gained.

Between these two groups was Diet 2, where $L$ value was lower than in Control 1 and Diet 1 and higher than in Control 2 and Diet 3 and Diet 4 , while $a^{*}$ value was higher than in Control 1 and Diet 1 and lower in Control 2, Diet 3 and Diet 4, thus this can be a desired color by consumers due to enough share of red tone, but smaller than in the group with synthetic pigments.

Result of RYCF color measurements showed that Diet 3 and Diet 4 resulted in yolk color similar to that of Control 2 diet with no significant differences $(p>0.05)$ (14.33 and 14.71 compared to 14.63 ).

However, since the preferred yolk color in Europe ranges from 10 to 14 , it can be said that Diet 2 provided the most favorable color and it can be recommended from this point of view.

However, Diet 3 showed the result just slightly above 14 RYCF.

Since our investigation of $\beta$-carotene content in egg yolk and color preferences according to RYCF has given controversy recommendation for the most applicative diet, our experiment covered also investigation of acceptability of yolk color. The results are shown in Fig. 2.

The results clearly presented that acceptability of yolk color did not differ significantly ( $p>0.05$ ) for the diets: Control 1, Control 2, Diet 1 and Diet 4 . The best acceptability of color was achieved with the Diet 2 , as it was shown by RYCF, too.

\section{CONCLUSIONS}

Presented results showed that natural pigment sources such as dried carrot and milled paprika can successfully replace synthetic pigments, with no negative effects on egg yolk color in terms of acceptability or $\beta$-carotene content. What is even more, combination of $1 \%$ of dried carrot and $0.5 \%$ of milled paprika in laying hens diet gave the most favorable egg yolk color according to evaluation by trained panelists.

\section{ACKNOWLEDGEMENTS}

This paper is a result of the research within the project III046012 financed by the Ministry of Education, Science and Technological Development, Republic of Serbia.

\section{REFERENCES}

1. Arimboor, R., Natarajan ,R.B., Menon, K.R., Chandrasekhar, L.P., Moorkoth ,V. (2014). Red 
pepper (Capsicum annuum) carotenoids as a source of natural food colors: analysis and stability- a review. Journal of Food Science and Technology, 52 (3), 1258-1271.

2. Cervantes-Paz, B., Yahia, E.M., de Jesús Ornelas-Paz, J., Victoria-Campos, C.I., IbarraJunquera, V., Pérez-Martínez, J.D., EscalanteMinakata, P. (2014). Antioxidant activity and content of chlorophylls and carotenoids in raw and heat-processed Jalapeño peppers at intermediate stages of ripening. Food Chemistry, 146, 188-196.

3. Chowdhury, S.D., Hassin, B.M., Das, S.C., Rashid, M.H., Ferdaus, A.J. (2008). Evaluation of marigold flower and orange skin as sources of xanthophyll pigment for the improvement of egg yolk color. The Journal of Poultry Science, 45 (4), 265-272.

4. Deepa, N., Kaur, C., George, B., Singh, B., Kapoor, H.C. (2007). Antioxidant constituents in some sweet pepper (Capsicum annuum L.) genotypes during maturity. $L W T$-Food Science and Technology, 40 (1), 121-129.

5. EFSA Panel on Additives and Products or Substances used in Animal Feed (FEEDAP). (2014). Scientific opinion on the safety and efficacy of canthaxanthin as a feed additive for poultry and for ornamental birds and ornamental fish. EFSA Journal, 12 (1), 3527.

6. Galobart, J., Sala, R., Rincón-Carruyo, X., Manzanilla, E.G., Vila, B., Gasa, J. (2004). Egg yolk color as affected by saponification of different natural pigmenting sources. Journal of Applied Poultry Research, 13 (2), 328-334.

7. Grashorn, M.A., Steinberg, W. (2002). Deposition rates of canthaxanthin in egg yolks. Archiv für Geflügelkunde, 66 (6), 258-262.

8. Gurbuz, Y., Yasar, S., Karaman, M. (2003). Effects of addition of the red pepper from 4th harvest to corn or wheat based diets on eggyolk colour and egg production in laying hens. International Journal of Poultry Science, 2 (2), 107-111.
9. Hammershøj, M., Kidmose, U., Steenfeldt, S. (2010). Deposition of carotenoids in egg yolk by short-term supplement of coloured carrot (Daucus carota) varieties as forage material for egg-laying hens. Journal of the Science of Food and Agriculture, 90 (7), 1163-1171.

10. Hernandez, J.M., Beardswort, P.M., Weber, G. (2005). Egg quality - meeting consumer expectations. International Poultry Production, 13 (3), 20-23.

11. Islam, K.M.S., Schweigert F.J. (2015). Comparison of three spectrophotometric methods for analysis of egg yolk carotenoids. Food Chemistry, 172, 233-237.

12. Lokaewmanee, K., Yamauchi, K., Komori, T., Saito K. (2011). Enhancement of egg yolk color by paprika combined with a probiotic. Journal of Applied Poultry Research, 20 (1), 90-94.

13. Rowghani, E., Maddahian, A., Abousadi, M.A. (2006). Effects of addition of marigold flower, safflower petals, and red pepper on egg-yolk color and egg production in laying hens. Pakistan Journal of Biological Sciences, 9 (7), 1333-1337.

14. SCF (1997). Minutes of the $107^{\text {th }}$ Meeting of the Scientific Committee for Food, Brussels, Belgium.

15. Spasevski, N., Čolović, D., Rakita, S., Ikonić, P., Đuragić, O., Banjac, V., Vukmirović, Đ. (2016). Fatty acid composition and $\beta$-carotene content in egg yolk of laying hens fed with linseed, paprika and marigold. Contemporary Agriculture, 65 (1-2), 15-22.

16. Spasevski, N., Tasić, T., Vukmirović, Đ., Banjac, V., Rakita, S., Lević, J., Đuragić, O. (2017). Effect of different levels of marigold and paprika on egg production and yolk colour. Archiva Zootechnica, 20 (2), 51-57.

17. SRPS EN ISO 8586:2015. Sensory analysis General guidelines for the selection, training and monitoring of selected assessors and expert sensory assessors. Institute for Standardization. Belgrade, Serbia. 


\section{УТИЦАЈ ДОДАТКА ШАРГАРЕПЕ И ПАПРИКЕ НА ФИЗИЧКЕ КАРАКТЕРИСТИКЕ ЈАЈА И БОЈУ ЖУМАНЦА}

Недељка Ј. Спасевски*, Данка М. Драгојловић, Душица С. Чоловић, Страхиња Ж. Видосављевић, Татјана А. Пеулић, Слађана М. Ракита, Бојана М. Кокић

Универзитет у Новом Саду, Институт за прехрамбене технологије у Новом Саду, 21000 Нови Сад, Булевар цара Лазара 1, Србија

Сажетак: За многе потрошаче боја жуманца је врло важна карактеристика квалитета јаја. Пошто кокоши носиље нису у стању да синтетишу обојене пигменте, интензитет боје жуманца зависи директно од садржаја и профила пигмената каротеноида који су присутни у њиховој храни. Циљ овог истраживања био је да се процени комбиновани ефрекат пигмента паприке и шаргарепе и да се види да ли комбиновани извори пигмента могу постићи боју жуманца у жељеном распону боја. Биолошки тестови су трајали 30 дана и изведени су на 180 јединки кокоши носиља расе „Lohmann Brown”. Кокоши носиље су биле подељене у шест група. Свакој групи је био додељен један од шест могућих третмана, контрола 1 (Ц1) третман без додавања пигмената, контрола 2 (Ц2) третман са синтетичким пигментима и четири експерименталне дијете (Д1, Д2, Д3, Д4) уз додавање природних извора боја (паприка и шаргарепа). Након експерименталног периода сакупљена јаја су анализирана у погледу фризичких карактеристика јаја, садржаја $\beta$-каротена и боје жуманца. Добијени резултати су показали да сува шаргарепа и млевена паприка могу успешно заменити синтетичке пигменте, без икаквих негативних ефеката на фризичке карактеристике произведених јаја, боју жуманца, прихватљивост или садржај $\beta$-каротена.

Кључне речи: природни пигменти, боја жуманца, CIE $L^{*} a^{*} b^{*}$, сензорна анализа, $\beta$ каротен

Received: 25 April 2018

Received in revised form: 29 May 2018

Accepted: 4 June 2018 